\title{
Initial reconnaissance for a South Georgia ice core
}

\author{
P. A. MAYEWSKI, ${ }^{1}$ A. KULI, ${ }^{1}$ G. CASASSA, ${ }^{2,3}$ M. ARÉVALO, ${ }^{3}$ D. A. DIXON, ${ }^{1}$ \\ B. GRIGHOLM, ${ }^{1}$ M. J. HANDLEY, ${ }^{1}$ H. HOFFMANN, ${ }^{4}$ D. S. INTRONE, ${ }^{1}$ A. G. KULI, ${ }^{1}$ \\ M. POTOCKI, ${ }^{1}$ S. B. SNEED ${ }^{1}$ \\ ${ }^{1}$ Climate Change Institute, University of Maine, Orono, Maine, USA \\ ${ }^{2}$ Geoestudios, Santiago, Chile \\ ${ }^{3}$ Universidad Magallanes, Punta Arenas, Chile \\ ${ }^{4}$ Institut für Umweltrphysik, Universität Heidelberg, Germany \\ Correspondence: P. A Mayewski<paul.mayewski@maine.edu>
}

\begin{abstract}
We present the first snow/ice chemistry and ice radar results ever collected from South Georgia as part of an initial reconnaissance with the ultimate goal of assessing the feasibility of a South Georgia ice core to reconstruct past climate in the South Atlantic. South Georgia is well situated to capture a record of past atmospheric chemical composition over the South Atlantic and of past variability in the position and intensity of the austral westerlies. The question is how well preserved an ice core record can be recovered from a region experiencing accelerated melting? The results presented in this paper offer only a preliminary step in determining the feasibility of future deep ice coring on South Georgia. However, this initial reconnaissance does provide some basic information including: the chemistry of the atmosphere over South Georgia relative to other Southern Hemisphere ice coring sites; the potential for preservation of 'annual layers' in old ice on the island; a possible age for deep ice in the region; and an estimate of glacier health in the lower elevation regions of the island.
\end{abstract}

KEYWORDS: Sub Antarctic islands, climate change, ice cores, glacier volume, ice chemistry, radio echo sounding

\section{INTRODUCTION}

In recent decades, air temperatures over portions of coastal Antarctica, the Southern Ocean and the winter atmosphere over Antarctica have exhibited record warming resulting in catastrophic disintegration of Antarctic ice shelves and coastal glaciers (ACCE, 2009). As a consequence of stratospheric ozone depletion over Antarctica and tropospheric greenhouse gas warming (Thompson and Solomon, 2002), there has been a significant poleward displacement of the polar jet and intensification of the polar westerlies (poleward (winter $3.38^{\circ} \mathrm{S}$; summer $1.88^{\circ} \mathrm{S}$ ) and intensifying (up to 6\%) between 1981-1990 and 2001-10) (Mayewski and others, 2012). The current rate and magnitude is potentially unsurpassed in the last $5200 \mathrm{a}$ (Mayewski and others, 2012). Further, the resultant steeper latitudinal $(\mathrm{N}-\mathrm{S})$ thermal gradient has left much of interior Antarctica at least temporarily isolated from the full force of greenhouse gas warming and sea ice extent surrounding much of Antarctica has increased (Turner and others, 2009).

Although warming is clearly impacting sub-Antarctic glacier extent (ACCE, 2009) ice core records recovered from carefully selected sites may still offer valuable reconstructions of past climate. South Georgia has a particularly advantageous location, placing it in the direct path of westerly winds (Fig. 1) dominated by marine air, and a variety of South American crustal, terrestrial biogenic and anthropogenic chemical sources from as far north as the Amazon. As a result South Georgia ice may contain records that capture past changes in the intensity and latitudinal range of atmospheric circulation systems such as the westerlies. Changes in the strength and position of the westerlies have significant impacts on moisture balance, storminess and northward penetration of cold surface ocean currents on both the west and east coasts of southern South America (Mayewski and others, 2015). South Georgia also receives intermittent air mass intrusions from the sub-tropics of eastern South America associated with El Niño (La Niña) southward (northward) displacement of mean circulation over the South Atlantic (Yuan, 2004) that could be useful in assessing polar-tropical teleconnections. Finally changes in air chemistry resulting from changes in the passageways of air masses over chemistry source regions could impact nutrient deposition over marine and terrestrial ecosystems in the South Atlantic region. South Georgia is, therefore, well placed to offer a record of past climate change over the South Atlantic. The major uncertainty, however, is how complete or robust an ice core record remains in South Georgia?

South Georgia's climate is classified as polar since it is south of the Polar Front. At sea level, winter temperatures are close to freezing (Fig. 2) and proximity to the Antarctic Current results in cold surface waters although, sea ice rarely forms around the island in winter. Dominant westerly winds result in harsher conditions on the northwestern side of the island compared with the southeast side, where descending winds yield milder and drier conditions. Annual precipitation is $\sim 1500 \mathrm{~mm}$ and summer snowline is $\sim 300 \mathrm{~m}$ a.s.l. on the northwest side of the island (https://en.wikipedia.org/ wiki/SouthGeorgiaandtheSouthSandwichlslands). Incoming radiation levels are low (maximum $\sim 21 \%$ of total available) due to clouds and local topography. Elevations on the island's interior plateau are up to $1000 \mathrm{~m}$ a.s.l. and climbing teams (S. Novak, 2014, personal communication) report the presence of dry snow zones on the interior plateau, indicating suitable conditions for a well preserved ice core record in these regions. The highest peak on the Island is Mount Paget (2935 m a.s.I.), but this 


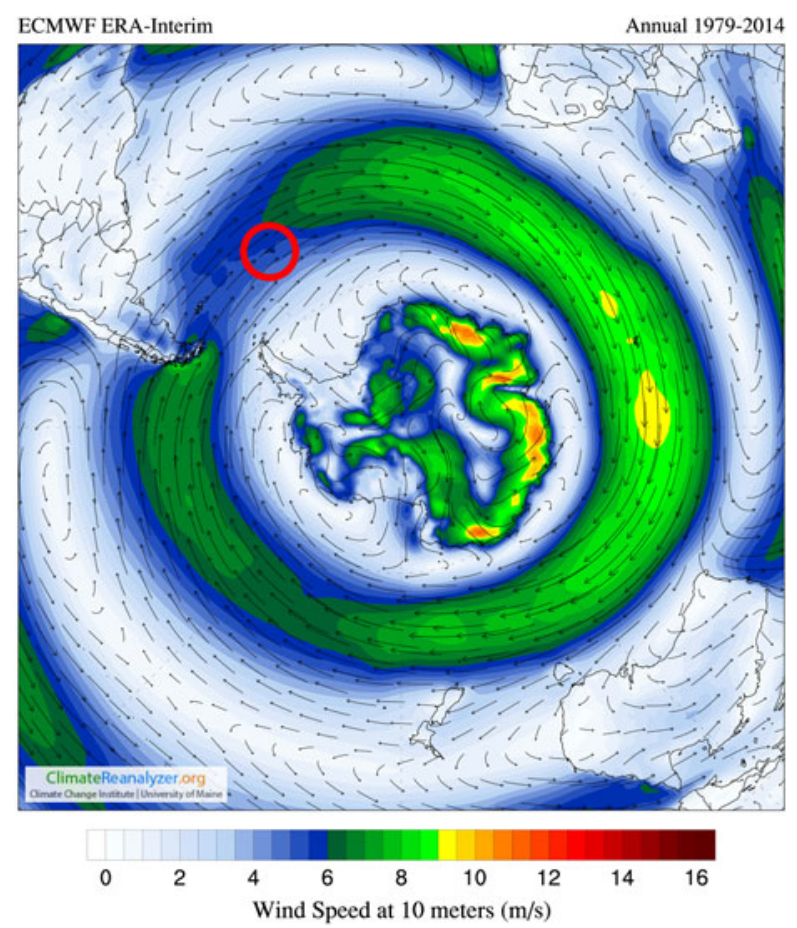

Fig. 1. Red circle indicates location of South Georgia directly in the path of the westerlies.

mountain and others above $2000 \mathrm{~m}$ a.s.l. are either too small to preserve an ice cap or require helicopter support to avoid the heavily crevassed slopes surrounding the mountains. A limited number of climbing teams have ascended these mountains, but transport of equipment, needed for drilling to bedrock, through the crevasses and icefalls surrounding these sites is unrealistic. There is at this time no possibility of helicopter support on the island or from offshore so our search for a deep drilling site has been confined to regions, where future drilling could realistically be undertaken via oversnow traverse from the coast.

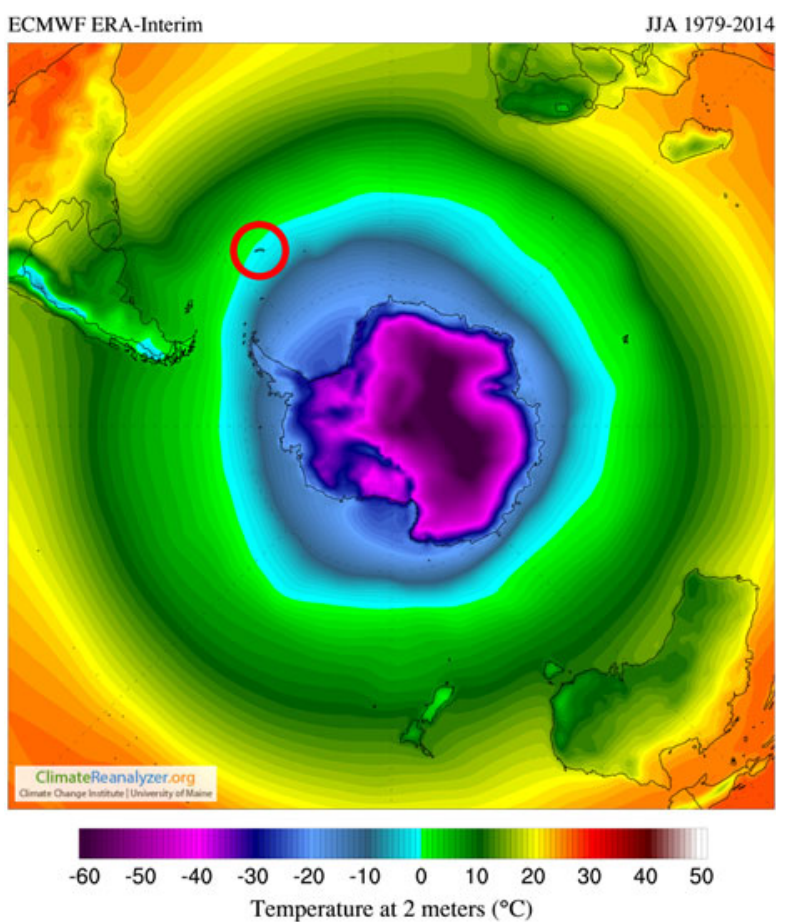

Fig. 2. Red circle indicates location of South Georgia within the Polar Front. Winter (JJA (June, July, August) temperature plotted.
Previous research on Marinelli Glacier in the Cordillera Darwin, Tierra del Fuego, at nearly the same latitude as South Georgia and at an elevation of $1823 \mathrm{~m}$ a.s.l. (Grigholm and others, 2009), revealed significant surface melting. The mean maximum temperature at Ushuaia, located on the coast, $90 \mathrm{~km}$ east of Marinelli Glacier, is $13^{\circ} \mathrm{C}$ (http://www.weather-and-climate.com), and occurs in January and February. Assuming a temperature lapse rate of $6^{\circ} \mathrm{C} \mathrm{km}^{-1}$, at an elevation of $1823 \mathrm{~m}$ on Cordillera Darwin, the mean maximum temperature in January/February should be $\sim+2{ }^{\circ} \mathrm{C}$. Clearly there must be warmer days with higher maximum temperature at $1823 \mathrm{~m}$ on Marinelli Glacier, but already a mean maximum temperature of $+2{ }^{\circ} \mathrm{C}$ is sufficiently high to explain the extensive snowmelt observed. A similar estimation for South Georgia suggests a mean maximum temperature of $-2{ }^{\circ} \mathrm{C}$ in February at an elevation of $1823 \mathrm{~m}$, based on a mean maximum temperature of $9^{\circ} \mathrm{C}$ recorded at Grytviken (http://www.weather-and-climate. com), located on the warmer northeastern coast of South Georgia. Therefore, cold snow and ice should definitely exist at elevations above $2000 \mathrm{~m}$ on South Georgia, with suitable microclimate conditions to preserve an ice core record. However, South Georgia is subjected to extremely strong winds year round that at elevation, could lead to significant loss of surface snow thus seriously compromising records retrieved from the highest regions of the island. Further, unlike the Cordillera Darwin, South Georgia is located south of the Polar Front so that ice located at lower elevations than $2000 \mathrm{~m}$ or very old ice retrieved through drilling and from glacier margins warrants reconnaissance investigation. Waiting much longer only increases the likelihood of losing any record that might still be preserved.

In October 2012 our research team joined a crew of three on board the $73^{\prime}$ sailboat Pelagic Australis and set sail to South Georgia from the Falkland Islands. Our goals were to retrieve a shallow firn core, to assess the potential for identifying 'annual layering' in old ice, and to conduct preliminary ice radar measurements. Our window of opportunity for this first reconnaissance was significantly shortened by unusually heavy October winds, so we did not have sufficient time to collect a firn core from our proposed site on the Kohl Plateau (Fig. 3) at $2900 \mathrm{~m}$ a.s.l., however, we were able to collect preliminary information that highlights the valuable climate record potentially available from a South Georgia ice core and confirms the potential for more detailed future investigations. In the short period available for fieldwork we collected one $2.5 \mathrm{~m}$ deep snowpit at $550 \mathrm{~m}$ a.s.l. from Szielasko Ice Cap on the Barff Peninsula (Fig. 3). Unfortunately this is the warmer north side of the island and the site is surrounded by ice free, dark rock. The snowpit yielded unmelted winter/spring snow deposited over ice, which was no doubt, refrozen melt from the previous warm season or older. At Szielasko Ice Cap we also measured surface elevation and ice thickness with radar sounding, to assess the potential span of an ice core record and to evaluate recent elevation changes. In addition, we collected two short $(\sim 1 \mathrm{~m})$ cores from the terminal reaches of the Nordenskjöld and Fortuna Glaciers on the northeastern side of the island (Fig. 3). While none of these locations are suitable for the collection of continuous ice core records that include modern snow, they do represent the first chemical sampling of snow and ice from South Georgia and the results offer promise for future study. 


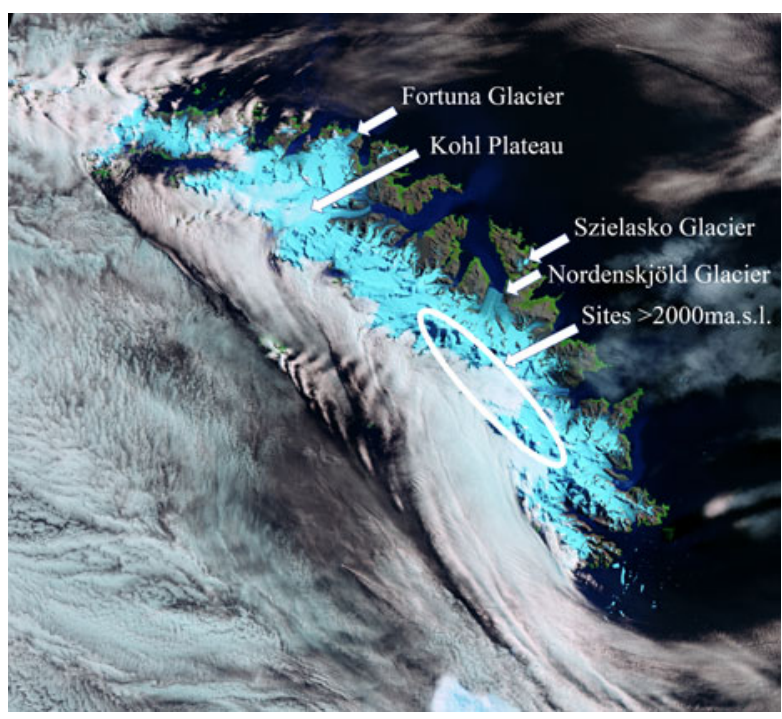

Fig. 3. Image captured by the Landsat- 8 satellite on 16 February 2015 USGS/ESA. South Georgia is $\sim 186 \mathrm{~km}$ from northwest to south east and $\sim 36 \mathrm{~km}$ at its widest point.

\section{ICE CORE CHEMISTRY - METHODS AND RESULTS}

We utilized the Climate Change Institute's W.M. Keck Laser Ice Core Facility LA-ICP-SFMS (Laser Ablation-Inductively Coupled Plasma-Sector Field Mass Spectrometry) system for the ultra-high resolution glaciochemical analyses of the ice cores reported in this study. Components include a Thermo Element 2 ICP-SFMS (also used for the lower resolution trace element sampling of the snowpit in this study), coupled to a New Wave UP-213 laser system and the Sayre Cell ${ }^{\mathrm{TM}}$, a cryocell chamber designed to seal a $1 \mathrm{~m}$ ice core from the surrounding air, while maintaining a uniform temperature of $\sim-15^{\circ} \mathrm{C}$, and a $121 \mu \mathrm{m}$ sampling resolution (Sneed and others, 2015). Hydrogen isotope ratios ( $\delta \mathrm{D})$ were measured via $\mathrm{Cr}$ reduction with a Eurovector elemental analyzer coupled to a Micromass Isoprime mass spectrometer. Samples of particulate organic carbon for ${ }^{14} \mathrm{C}$ analysis were decontaminated, extracted and combusted at Heidelberg University resulting in $\mathrm{CO}_{2}$-gas for direct ${ }^{14} \mathrm{C}$ analysis via the gas ion source at the MICADAS-AMS in Mannheim (Kromer and others, 2013).

${ }^{14} \mathrm{C}$ measurements were made on ice from the short cores recovered at the margins of Fortuna and Nordenskjöld Glaciers. Calibrated ${ }^{14} \mathrm{C}$ ages of 8633-9397 a BP and 10 295-10 997 a BP, respectively, suggest that the ice terminii age, potentially the oldest ice on the island, could be in the range 8500-11 000 a BP. While we report these dates, we caution that future investigation, including ${ }^{14} \mathrm{C}$ dating of local ice-free region materials is clearly essential, in light of reservoir effects potentially introduced by the incorporation of local dusts and sediment.

Figure 4 shows $\delta \mathrm{D}$ from the Szielasko snowpit and the Fortuna and Nordenskjöld terminii short cores. We assume that the snowpit data covers winter/spring 2011/12 and the range, -170 to $-100 \%$, suggests significant enough variability to represent storms or seasons. Lacking longer records, it is unclear if the values are controlled by temperature, snow accumulation rate, transport distance and/or source region. The significantly older glacier margin short cores reveal significantly less depleted values (Fortuna -62 to -54 ; Nordenskjöld -99 to -81 ) and significantly subdued variability suggesting post-depositional alteration of the water isotope record or possibly warmer and shorter transport conditions 8500-11 000 a ago, which if the ${ }^{14} \mathrm{C}$ age is correct, coincide with widespread Antarctic early Holocene warming from 9000 to 11500 a BP (Steig and others, 2000).

Figure 4 also reveals calcium (crustal source), iron (crustal and marine source), and sodium (marine source) ICP-SFMS
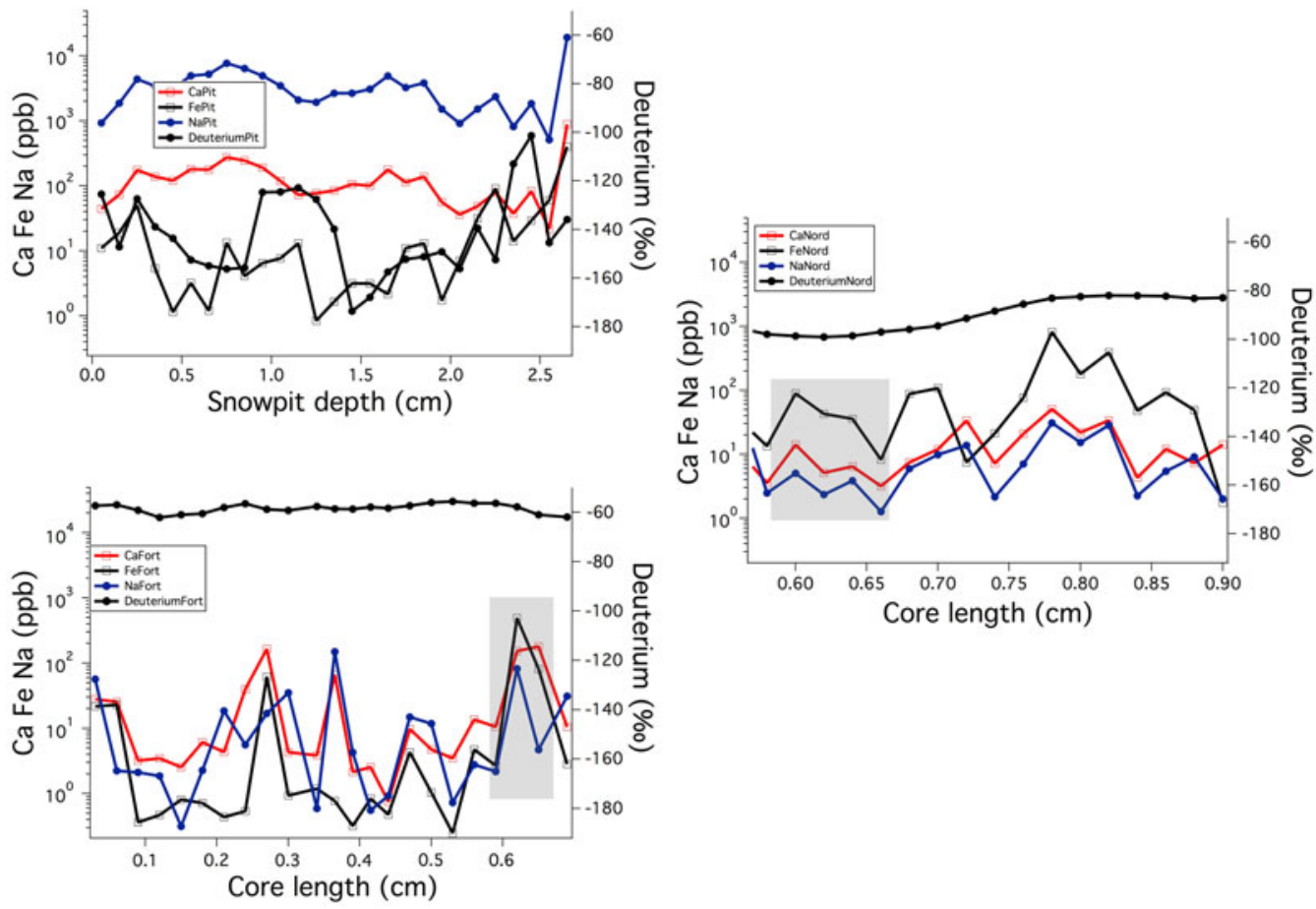

Fig. 4. $\delta \mathrm{D}$ (deuterium), calcium, iron and sodium ICP-SFMS values for Szielasko snowpit, Fortuna and Nordenskjöld Glacier terminii ice cores. Gray highlighting shows sections analyzed by LA-ICP-SFMS in Figure 5. 

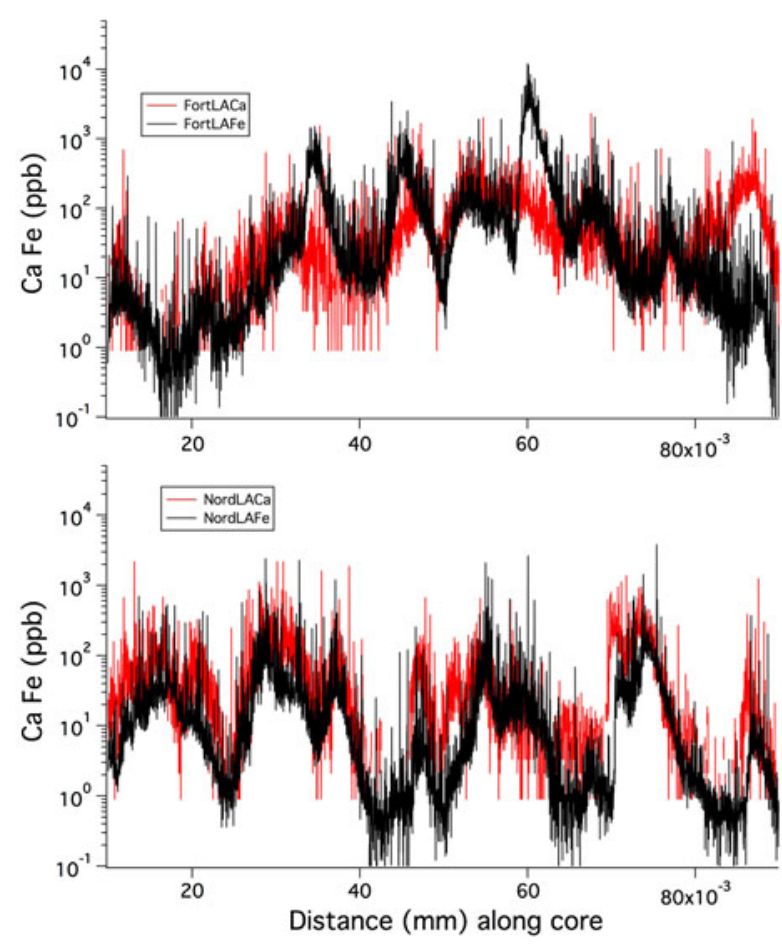

Fig. 5. Calcium and iron LA-ICP-SFMS for Fortuna and Nordenskjöld termini ice samples. Location of samples highlighted in gray in Figure 4.

derived concentrations for the Szielasko snowpit, and for the Fortuna and Nordenskjöld terminii cores. Winter/spring Szielasko snowpit concentrations are higher in calcium than most of the core samples. Winter/spring Szielasko iron concentration is in between those of Nordenskjöld and Fortuna, respectively. Szielasko sodium concentration is notably higher than in either core. The generally higher calcium and notably higher sodium concentrations in modern winter/spring snow may suggest stronger westerly winds and/or a more exposed local dust sources, albeit based on limited data.

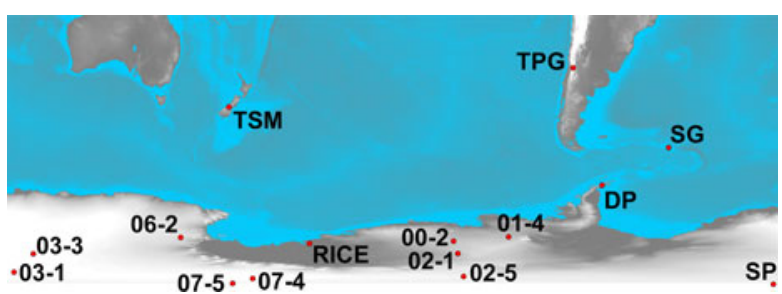

Fig. 6. Distribution of concentration data presented in Table 1. Map base from ETOPO1 (Amante and Eakins, 2009).

To investigate the potential for the preservation of 'annual layers', $121 \mu$ ultra-high resolution LA-ICP-SFMS measurements from $9 \mathrm{~cm}$ long sections of the termini cores are presented in Figure 5. Perhaps most intriguing is the $\sim 10 \mathrm{~mm}$, fairly consistent variability in both the Fortuna and Nordenskjöld LA-ICP-SFMS calcium and iron data. The variability is similar to that induced by 'annual layering'. However, knowledge of modern day annual layering (net mass balance) is needed before assigning the variability described here as 'annual'. Nevertheless there is the potential to recover a long record of 'annually-resolved' past mass balance potentially covering the Holocene.

Figure 6 and Tables 1 and 2 provide an initial comparison of the levels of crustal ( $\mathrm{Sr}, \mathrm{Ba}, \mathrm{La}, \mathrm{Ce}, \mathrm{Pb}, \mathrm{Li}, \mathrm{S}, \mathrm{Ca}, \mathrm{Ti}, \mathrm{Mn}, \mathrm{Fe}$, $\mathrm{Na}, \mathrm{Mg}$ ), marine ( $\mathrm{Sr}, \mathrm{Ba}, \mathrm{Pb}, \mathrm{S}, \mathrm{Ca}, \mathrm{Fe}, \mathrm{Na}, \mathrm{Mg}$ ) and anthropogenic $(\mathrm{Ba}, \mathrm{Pb}, \mathrm{S})$ source elements from ice core sites in Antarctica, Chile, New Zealand and South Georgia. Levels of several elements $(\mathrm{Sr}, \mathrm{Ba}, \mathrm{La}, \mathrm{Ce}, \mathrm{Pb}, \mathrm{Li}, \mathrm{S}, \mathrm{Ca}, \mathrm{Ti}, \mathrm{Mn}$, $\mathrm{Fe}, \mathrm{Na}, \mathrm{Mg}$ ) are in general higher for extra-Antarctic sites (South Georgia, New Zealand (Tasman) and the Chilean Andes (TPG) than for northerly Antarctic sites (Antarctic Peninsula (DP), and coastal West Antarctica (RICE), which in turn are higher than West Antarctic (ITASE; Dixon and others, 2013) and South Pole (SPRESSO; Korotkikh and others, 2014) ice core values. Szielasko winter snowpit values for $\mathrm{Sr}, \mathrm{Na}$, and $\mathrm{Mg}$ are the highest in the record demonstrating the significant marine influence impacting South Georgia. Anomalously high Ba values at South Pole are attributed to local station anthropogenic sources (building

Table 1. Time period covered, site name and location for records presented in Figure 6

\begin{tabular}{|c|c|c|}
\hline Time period & Core or snowpit & Location \\
\hline Winter 2012 & SG-12-snowpit & Szelasko Ice Cap, South Georgia \\
\hline 10474 a BP & SG-12-Fortuna & Glacier terminus, South Georgia \\
\hline 9010 a BP & SG-12-Nordenskjold & Glacier terminus, South Georgia \\
\hline 1981-2011 & TPG-12-1 & Tupungatito Glacier, Chile \\
\hline $1981-2007$ & DP-07-1 & Detroit Plateau, Antarctic Peninsula \\
\hline $2002-10$ & RICE & Roosevelt Island, West Antarctica \\
\hline 1988-2000 & ITASE-00-2 & West Antarctica \\
\hline 1980-2001 & ITASE-01-4 & West Antarctica \\
\hline 1980-2002 & ITASE-02-1 & West Antarctica \\
\hline $1966-1975$ & ITASE-02-1 & West Antarctica \\
\hline $1967-1975$ & ITASE-02-5 & West Antarctica \\
\hline $1960-1983$ & ITASE-03-1 & West Antarctica \\
\hline $1955-1975$ & ITASE-03-1 & West Antarctica \\
\hline $2002-06$ & ITASE-06-2 & West Antarctica \\
\hline $2000-2006$ & ITASE-07-4 & West Antarctica \\
\hline 2000-2006 & ITASE-07-5 & West Antarctica \\
\hline 1992-2005 & Tasman Glacier & New Zealand Alps \\
\hline
\end{tabular}


Table 2. Mean chemical concentration data for sites compared in this study (Fig. 6)

\begin{tabular}{|c|c|c|c|c|c|c|c|c|c|c|c|c|c|}
\hline Core or snowpit & $\begin{array}{l}\mathrm{Sr} \\
\mathrm{ng} \mathrm{L}^{-1}\end{array}$ & $\begin{array}{l}\text { Вa } \\
n g L^{-1}\end{array}$ & $\begin{array}{l}\mathrm{La} \\
\mathrm{ng} \mathrm{L}^{-1}\end{array}$ & $\begin{array}{l}\mathrm{Ce} \\
\mathrm{ng} \mathrm{L}^{-1}\end{array}$ & $\begin{array}{l}\mathrm{Pb} \\
\mathrm{ng} \mathrm{L}^{-1}\end{array}$ & $\begin{array}{l}\mathrm{Li} \\
\mathrm{ng} \mathrm{L}^{-1}\end{array}$ & $\begin{array}{l}\mathrm{S} \\
\mu \mathrm{g} \mathrm{L}^{-1}\end{array}$ & $\begin{array}{l}\mathrm{Ca} \\
\mu \mathrm{g} \mathrm{L}^{-1}\end{array}$ & $\begin{array}{l}\mathrm{Ti} \\
\mathrm{ng} \mathrm{L}^{-1}\end{array}$ & $\begin{array}{l}\mathrm{Mn} \\
\mathrm{ng} \mathrm{L}^{-1}\end{array}$ & $\begin{array}{l}\mathrm{Fe} \\
\mu \mathrm{g} \mathrm{L}^{-1}\end{array}$ & $\begin{array}{l}\mathrm{Na} \\
\mu \mathrm{g} \mathrm{L}^{-1}\end{array}$ & $\begin{array}{l}\mathrm{Mg} \\
\mu g \mathrm{~L}^{-1}\end{array}$ \\
\hline SG-12-snowpit & 3619.00 & 336.39 & 18.55 & 43.83 & 55.40 & 102.90 & 346.57 & 142.79 & 974.02 & 1529.61 & 29.75 & 3677.70 & 426.67 \\
\hline SG-12-Fortuna & 141.73 & 233.95 & 47.18 & 120.80 & 123.46 & 22.36 & 2.25 & 32.27 & 1205.99 & 1012.86 & 30.53 & 19.44 & 6.27 \\
\hline SG-12-Nordenskjold & 103.38 & 239.25 & 8.51 & 28.17 & 67.19 & 54.00 & 2.10 & 14.94 & 5608.56 & 2491.59 & 116.83 & 11.64 & 21.46 \\
\hline TPG-12-1 & 2743.59 & 2131.15 & 113.35 & 269.37 & 588.19 & 129.70 & 376.44 & 518.50 & 4399.86 & 7928.98 & 149.84 & 55.53 & 105.51 \\
\hline DP-07-1 & 215.71 & 24.15 & 0.35 & 0.78 & 6.20 & 8.17 & 36.15 & 9.51 & 33.09 & 24.56 & 0.55 & 337.63 & 31.78 \\
\hline RICE & 389.13 & 80.69 & 0.93 & 1.81 & 19.75 & 9.29 & 92.71 & 58.49 & 64.27 & 55.64 & 2.84 & 431.26 & 48.47 \\
\hline SPRESSO & 22.24 & 296.04 & 0.50 & 0.86 & 30.12 & 14.70 & 7.76 & 4.31 & 34.67 & 82.23 & 2.48 & 7.89 & 6.76 \\
\hline ITASE-00-2 & 14.07 & 5.86 & 0.13 & 0.34 & 7.09 & & 6.96 & 1.32 & 16.36 & 18.14 & 0.40 & 15.99 & 3.53 \\
\hline ITASE-01-4 & 11.44 & 7.63 & 0.30 & 0.65 & 4.90 & 1.38 & 7.94 & 1.29 & 23.18 & 20.43 & 0.72 & 13.75 & 5.22 \\
\hline ITASE-02-1 & 17.12 & 11.89 & 0.28 & 0.45 & 15.94 & 1.27 & 8.99 & 2.24 & 18.59 & 38.48 & 2.64 & 24.95 & 4.41 \\
\hline ITASE-02-1 & 30.78 & 6.52 & 0.25 & 0.46 & 4.50 & 1.47 & 10.17 & 3.43 & 31.85 & 28.86 & 0.49 & 41.60 & 6.42 \\
\hline ITASE-02-5 & 13.46 & 7.25 & 0.30 & 0.60 & 2.27 & & 17.32 & 2.46 & 17.55 & 19.52 & 0.37 & 18.01 & 1.80 \\
\hline ITASE-03-1 & 17.45 & 19.01 & 0.51 & 1.16 & 21.72 & & 25.10 & 1.05 & 36.53 & 30.22 & 0.97 & 15.19 & 4.51 \\
\hline ITASE-03-1 & 16.73 & 18.19 & 0.51 & 1.15 & 20.93 & & 25.93 & 0.95 & 35.10 & 29.60 & 0.99 & 14.63 & 4.49 \\
\hline ITASE-03-3 & 46.61 & 27.44 & 2.53 & 4.43 & 24.99 & 5.02 & 58.23 & 4.23 & 63.94 & 67.26 & 2.34 & 45.43 & 11.65 \\
\hline ITASE-06-2 & 19.59 & 6.36 & 0.80 & 1.85 & 6.06 & 2.44 & 18.38 & 3.38 & 66.31 & 15.95 & 0.86 & 19.03 & 2.76 \\
\hline ITASE-07-4 & 8.46 & 5.34 & 0.22 & 0.51 & 1.51 & 1.82 & 9.48 & 0.90 & 42.83 & 7.09 & 0.42 & 8.05 & 1.58 \\
\hline ITASE-07-5 & 10.93 & 5.12 & 0.41 & 0.88 & 3.28 & 1.05 & 12.71 & 2.53 & 59.73 & 12.41 & 0.89 & 10.72 & 2.77 \\
\hline Tasman Glacier & 82.72 & 34.98 & 1.09 & 2.32 & 15.84 & 10.26 & 13.35 & 18.33 & 63.46 & 72.37 & 1.71 & 128.41 & 8.65 \\
\hline TPG-12-1 & 2743.59 & 2131.15 & 113.35 & 269.37 & 588.19 & 129.70 & 376.44 & 518.50 & 4399.86 & 7928.98 & 149.84 & 55.53 & 105.51 \\
\hline
\end{tabular}

All data were collected by and analyzed by the Climate Change Institute. 


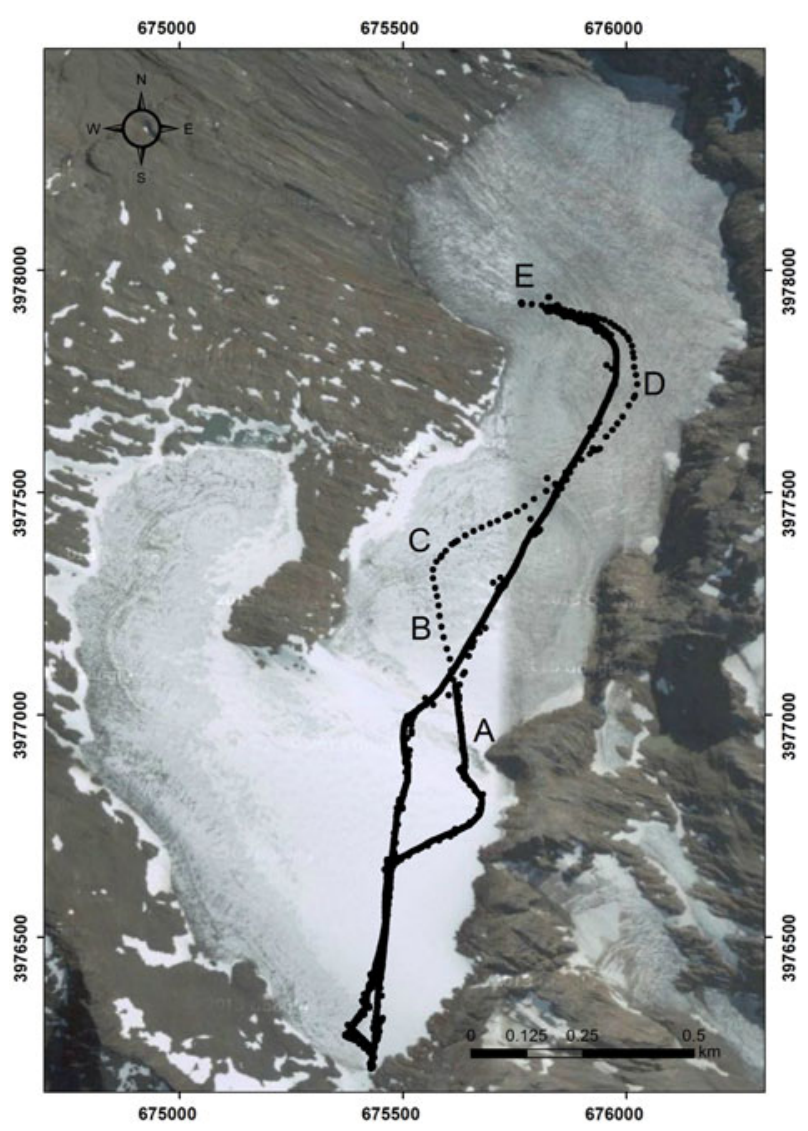

Fig. 7. Szielasko Glacier. The image is $1.6 \mathrm{~km}$ wide (east-west) and 2.5 $\mathrm{km}$ long (north-south). The black path represents the radar/GPS track performed on 18 October 2012 and the lowest elevation is marked as ' $\mathrm{D}$ '. The radar profile $\mathrm{ABCDE}$ was measured on the return track, and the corresponding radargram is shown in Figure 8. A maximum ice depth of $76 \mathrm{~m}$ was measured at point B. Source: Google Earth.

materials and fuels) (Korotkikh and others, 2014), while mining in the Chilean Andes could explain the high $\mathrm{Ba}$ values for South Georgia.

\section{RADIO ECHO SOUNDING AND GPS - METHODS AND RESULTS}

A portable impulse radar with a central frequency of $4 \mathrm{MHz}$ was used with a transmitter to produce a pulse with an output voltage of $1600 \mathrm{~V}$, a rise time of $100 \mathrm{~ns}$ and a pulse repetition frequency of 400 pulses $\mathrm{s}^{-1}$. The receiver is composed of a Fluke PM97 oscilloscope connected to a portable PC that acts as a recording unit. Antennae with a half-dipole length of $20 \mathrm{~m}(\lambda / 4)$ were used in the field, equivalent to a wavelength $(\lambda)$ of $42 \mathrm{~m}$ in ice, assuming an electromagnetic wave velocity in temperate ice of $168 \mathrm{~m} \mathrm{ss}^{-1}$ (Blindow and others, 2010). Frequencies $<30$ $\mathrm{MHz}$ are especially adequate for temperate glaciers such as those found at lower elevations on South Georgia, since the presence of water bodies within the ice with a dimension on the order of several meters produces strong signal loss by scattering and absorption. The radar data were processed using the ReflexW program (K.J. Sandmeier software).

A single freguency GPS receiver with C/A code and pseudorange was used for geolocation of the radar data and also for monitoring the surface elevation of the glacier. The GPS data were differentially processed with data from the IGS (International GNSS Service (http://igs.org/rts) stations Falkland Islands (FALK, located $1470 \mathrm{~km}$ to the west) and O'Higgins Station (OHIG, located $1580 \mathrm{~km}$ southwest in the Antarctic Peninsula) using the GrafNav software combined with the online Precise Point Positioning (PPP) solution of the Canadian Spatial Reference System (http://www.geod. nrcan.gc.ca/products-produits/ppp_e.php). The elevation accuracy of the data is $4 \mathrm{~m}$.

A $2 \mathrm{~km}$ north-south and south-north radar and GPS transect, with a similar return track (total $4 \mathrm{~km}$ ), was completed on Szielasko Ice Cap on 18 October 2012 (Fig. 7). The Szielasko Glacier covers an area of $1.6 \mathrm{~km}^{2}$, with a total area of $\sim 3 \mathrm{~km}^{2}$ including neighboring ice-covered areas, which is $\sim 4 \%$ of the whole Barff Peninsula. Based on its size Szielasko is classified at present as a glacier, rather than an ice cap (Cogley and others, 2011).

The maximum ice depth along the radar transect is $86 \mathrm{~m}$. Figures 7 and 8 show a radar transect with a maximum ice
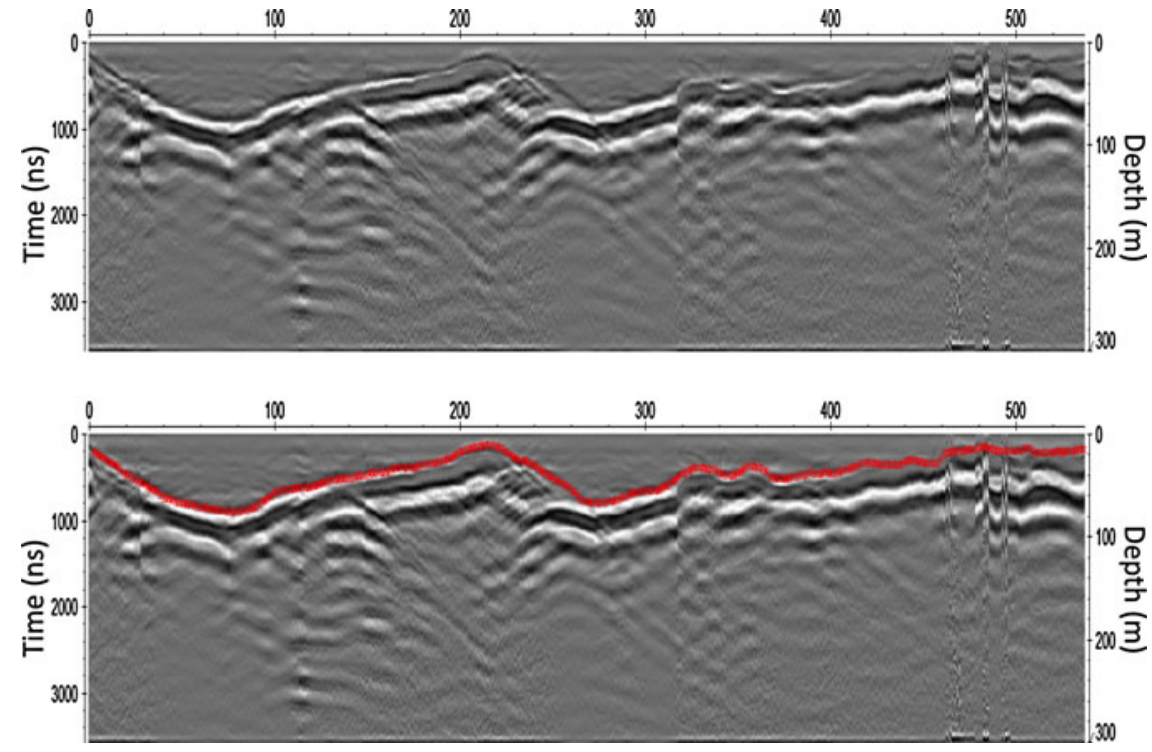

Fig. 8. Radargram corresponding to the profile $\mathrm{AA}^{\prime}$ shown in Figure 7. The left axis shows two-way travel time in ns, while the right axis is the equivalent ice depth in $\mathrm{m}$. The horizontal scale is expressed as number of radar traces, and corresponds to a horizontal distance of $1460 \mathrm{~m}$. The lower radargram is the same as the upper one, but with a red curve indicating the interpreted glacier bed. The maximum ice depth of profile $\mathrm{AA}^{\prime}$ occurs at trace $\mathrm{N}^{\circ} 76$ with $76 \mathrm{~m}$ (Figure 7). 


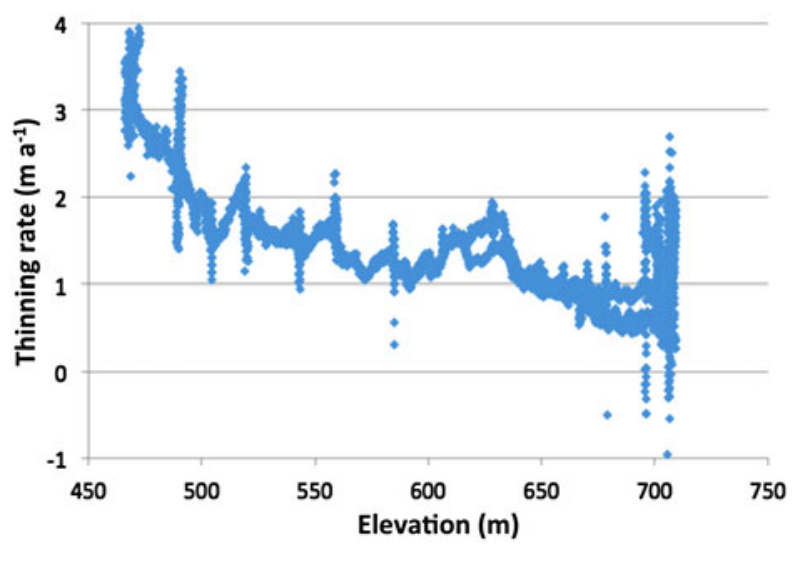

Fig. 9. Thinning rates $(\mathrm{m})$ at Szielasko Glacier were obtained from GPS 18 October 2012 data and SRTM February 20001 arcsec data. Thinning rates are maximum at lower elevations and minimum at the highest elevations.

thickness of $76 \mathrm{~m}$. Ice thicknesses have a nominal accuracy of $5 \mathrm{~m}$. These are the first reported ice thickness measurements of South Georgia, and will help to calibrate estimated ice depths (Cooper and others, 2010). For Szielasko Glacier, the estimated ice depth using a standard ice flow model based on SRTM surface elevations (Farr and others, 2007) is between 0 and $250 \mathrm{~m}$, with a $50 \%$ confidence (Cooper and others, 2010).

Comparison of our GPS data of 18 October 2012 with the 1 arcsecond (24.5 $\mathrm{m}$ horizontal resolution and vertical error of $8 \mathrm{~m}$ ) SRTM elevation data of February 2000 allows us to derive elevation changes for Szielasko Glacier. The total elevation change error is the quadrature sum of the GPS and the STRM errors. The absolute elevation errors of the GPS and the SRTM data (at 90\% probability level) are 4 and $8 \mathrm{~m}$, respectively, so the quadrature error is $9 \mathrm{~m}$. For an average thickness change over the area of Szielasko Glacier, the total error can be further divided by the square root of the number of GPS data points obtained (11773 data points at a rate of $1 \mathrm{~Hz}$ ), resulting in an elevation change error of $8 \mathrm{~cm}$. An average thinning of $20.38 \mathrm{~m}$ was obtained for the 12.7 a period, equivalent to an average thinning rate of $1.6 \mathrm{~m} \mathrm{a}^{-1}$. The thinning rate is maximum at lower elevations $\left(4 \mathrm{~m} \mathrm{a}^{-1}\right.$ at $\left.420 \mathrm{~m}\right)$ and minimum at higher elevations $\left(\sim 1 \mathrm{~m} \mathrm{a}^{-1}\right.$ at $\left.700 \mathrm{~m}\right)$ (Fig. 9).

Assuming a mean snow/firn density of $0.5 \mathrm{~g} \mathrm{~cm}^{3}$ at Szielasko Glacier, a mass loss of $0.8 \mathrm{~m}$ w.e. $\mathrm{a}^{-1}$ is obtained, that is in the upper range of the global average of glacier mass loss (Zemp and others, 2015) for the first decade of the $21 \mathrm{st}$ century, and the highest mass loss rate measured during the last 100 a. The large majority $(97 \%)$ of glaciers in South Georgia have been retreating since at least 1938, with 15 glaciers having retreated $>1 \mathrm{~km}$, and Neumayer Glacier on the northeastern coast exhibiting the largest retreat in South Georgia; $4.4 \mathrm{~km}$ in the period 1957-2008 (Cook and others, 2010). This accelerated retreat is most probably a response to warmer air and sea surface temperatures with impacts on albedo, glacier calving and other ablation processes. At Grytviken, on the northeast coast of South Georgia, summer temperatures are nearly $2^{\circ} \mathrm{C}$ higher than in the 1930s (Cooper and others, 2010).

If current glacier loss rates remain stable, peripheral lowelevation glaciers such as Szielasko would completely disappear within 50 a. Under future climate warming scenarios glacier extinction could probably occur earlier. On the main icefield of South Georgia the highest elevations are close to $1000 \mathrm{~m}$ and reach $2935 \mathrm{~m}$ a.s.l. at Mount Paget. Considering that the large majority of glaciers are retreating on South Georgia, any potential snow accumulation increase related to warming and intensification of the westerlies, has likely been counterbalanced by enhanced ablation due to temperature increase at lower elevations. Therefore we should expect ongoing accelerated glacier loss over South Georgia in the future.

\section{CONCLUSIONS}

Our data together with the inspection of climatological data suggest that a viable ice core climate record is available from South Georgia, particularly at elevations above 2000 m a.s.l. There exists a strong impetus for continuing the search for a well-preserved ice core site based on the following: (1) South Georgia is clearly in a region that is sensitive to and potentially severely impacted by changes in the position and strength of the westerlies; (2) glacier retreat in response to warming severely limits the availability of viable ice core recovery sites on South Georgia; (3) 'annual layering' could be preserved in old ice; (4) recent terrestrial dust (calcium) and seasalt (sodium) values suggest intensification of the westerly winds today relative to a snapshot in time tentatively assigned to the early Holocene; and (5) South Georgia glaciochemical concentrations are very high relative to West Antarctic and Antarctic Peninsula ice core sites, and similar to ice core sites in the Chilean Andes and the New Zealand Alps, as might be expected based on latitude and proximity to terrestrial and anthropogenic sources. It is clear that an ice core sampling site well above $550 \mathrm{~m}$ (ideally above $2000 \mathrm{~m}$ ), on the west side of the island (summer snowline $\sim 300 \mathrm{~m}$ ), far from exposed rock, is required to test the viability of a deeper ice core. Sites in the Kohl Plateau region at $\sim 1000 \mathrm{~m}$ a.s.l. or the small ice caps above $2000 \mathrm{~m}$ a.s.l. are likely candidates. The highest sites are subjected to intense winds and therefore significant erosion that could cause major erosional disconformities in resulting ice core records. Further they require helicopter support to transport deep drilling equipment, that is, at present, not available for South Georgia.

\section{ACKNOWLEDGEMENTS}

We wish to thank the crew (Magnus Day, Kali Kahn, and Edd Hewitt) and owner Skip Novak of Pelagic Australis for their amazing support, the Kuli Foundation for their generous funding, the Government of South Georgia and the South Sandwich Islands for permission to work on South Georgia and for their remarkable oversight of the island, the Government of the Falkland Islands and the South Atlantic Environmental Research Institute in the Falkland Islands for their advice and support, the British Antarctic Survey for allowing use of their freezer at the King Edward Point Station, and for transporting our ice samples to the UK from which we could transport them to Maine, two anonymous reviewers for their helpful comments, W.M. Keck Foundation and the US National Science Foundation 1042883) for support and enhancement of the W.M. Keck Laser Ice Facility at $\mathrm{CCl}$, and to the University of Heidelberg (Dietmar Wagenbach and Pascal Bohleber) for facilitating the ${ }^{14} \mathrm{C}$ measurements. 


\section{REFERENCES}

ACCE (Antarctic Climate Change and the Environment). editors Turner JT, Bindschadler R, Convey P, Prisco G, Fahrbach E, Hodgson D, Mayewski PA, Summerhayes C (2009) Scientific Committee for Antarctic Research, ISBN 978-0-948277-22-1

Amante C and Eakins BW (2009) ETOPO1 1 arc-minute global relief model: procedures, data sources and analysis. NOAA Technical Memorandum NESDIS NGDC-24. National Geophysical Data Center, NOAA, Boulder, CO, USA (doi: 10.7289/V5C8276M)

Blindow $\mathrm{N}$ and 8 others (2010) Geometry and thermal regime of the King George Island ice cap, Antarctica, from GPR and GPS. Ann. Glaciol., 51(55), 103-109

Cogley JG and 10 others (2011) Glossary of Glacier Mass Balance and Related Terms. IHP-VII Technical Documents in Hydrology No. 86, IACS Contribution No. 2, UNESCO-IHP, Paris

Cook AJ, Poncet S, Cooper APR, Herbert DJ and Christie D (2010) Glacier retreat on South Georgia and implications for the spread of rats. Antarct. Sci., 22(3), 255-263 (doi: 10.1017/ S0954102010000064)

Cooper APR, Tate JW and Cook AJ (2010) Estimating ice thickness in South Georgia from SRTM elevation data. Int. Arch. Photogram. Rem. Sens. Spatial Info. Sci., 38(Part II), 592-597 (doi: 10.1007/ 978-3-642-25926-5_17)

Dixon DA and 6 others (2013) Variations in snow and firn chemistry along US ITASE traverses and the effect of surface glazing. Cryosphere, 7(2), 515-535 (doi: 10.5194/tc-7-515-2013)

Farr TG and 17 others (2007) The shuttle radar topography mission. Rev. Geophys., 45 (doi: 1029/2005RG000183)

Grigholm BO and 5 others (2009) Chemical composition of fresh snow chemistry from the Marinelli Glacier, Tierra del Fuego. J. Glaciol., 55(193), 769-776
Korotkikh EV, Mayewski PA, Dixon D, Kurbatov AV and Handley MJ (2014) Recent increase in Ba concentrations as recorded in a South Pole ice core. Atmos. Environ., 89, 683-687

Kromer B, Lindauer S, Synal HA and Wacker L (2013) MAMS - a new facility at the Curt-Engelhorn-Centre for Archaeomoetry, Mannheim, Germany. Nucl. Instrum. Methods Phys. Res. B, 294, 11-13 (doi: 10.1016/j.nimb.2012.01.015)

Mayewski PA and 20 others (2012) West Antarctica's sensitivity to natural and human-forced climate change over the Holocene. J. Quat. Sci., 28(1), 40-48 (doi: 10.1002/jqs.2593)

Mayewski PA and 13 others (2015) Potential for Southern Hemisphere climate surprises. J. Quat. Sci. (Rapid Communication), 30(5), 391-395

Sneed SB and 9 others (2015) New LA-ICP-MS cryocell and calibration technique for sub-millimeter analysis of ice cores. J. Glaciology, 61(226), 233-242

Steig EJ and 6 others (2000) Wisconsinan and Holocene climate history from an ice core at Taylor Dome, western Ross Sea Embayment, Antarctica. Geogr. Ann., 82A, 213-235

Thompson DWJ and Solomon S (2002) Interpretation of recent Southern Hemisphere climate change. Science, 296(5569), 895-899 (doi: 10.1126/science.1069270)

Turner J and 12 others (2009) Non-annular atmospheric circulation change induced by stratospheric ozone depletion and its role in the recent increase of Antarctic sea ice extent. Geophys. Res. Lett., 36, L08502 (doi: 10.1029/2009GL037524)

Yuan X (2004) ENSO-related impacts on Antarctic sea ice: a synthesis of phenomena and mechanisms, Antarct. Sci., 16, 415-425 (doi: 10.1017/S0954102004002238)

Zemp $M$ and 46 others (2015) Historically unprecedented global glacier changes in the early 21 st Century. J. Glaciol., 61(228), 745-762 (doi: 10.3189/2015JoG15J017)

MS received 29 August 2015 and accepted in revised form 15 November 2015; first published online 16 March 2016) 